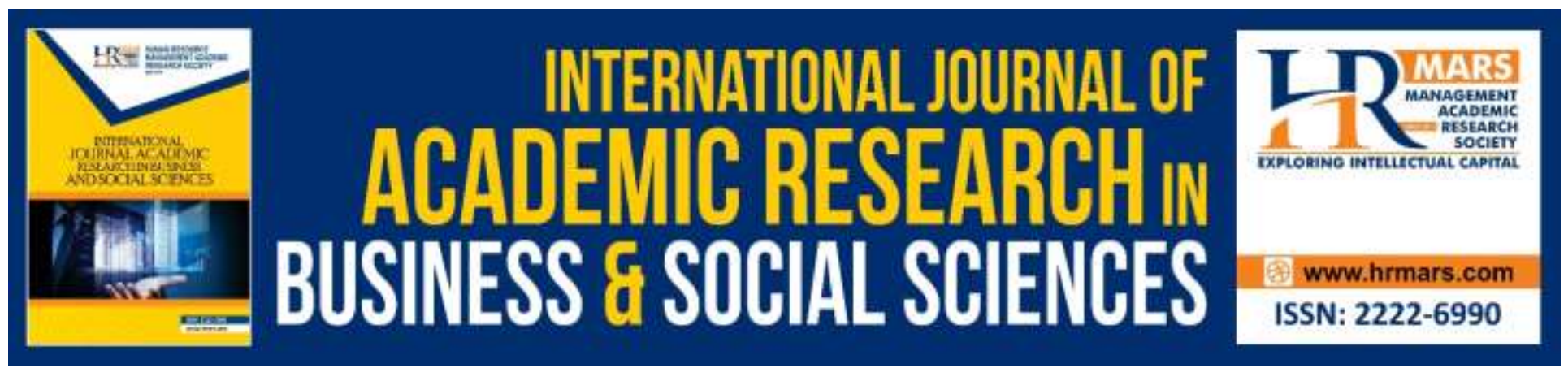

\title{
Evolution of the Tourist Offer in Romania in the Period of Accessing European Funds: Case Study, 2007 - 2015
}

\author{
Anamaria - Catalina Radu, Octavian Arsene
}

To Link this Article: http://dx.doi.org/10.6007/IJARBSS/v9-i6/6156

DOI: $10.6007 /$ IJARBSS/v9-i6/6156

Received: 13 April 2019, Revised: 12 May 2019, Accepted: 12 June 2019

Published Online: 29 June 2019

In-Text Citation: (Radu \& Arsene, 2019)

To Cite this Article: Radu, A. - C., \& Arsene, O. (2019). Evolution of the Tourist Offer in Romania in the Period of Accessing European Funds: Case Study, 2007 - 2015. International Journal of Academic Research in Business and Social Sciences, 9(6), 1290-1303.

Copyright: (C) 2019 The Author(s)

Published by Human Resource Management Academic Research Society (www.hrmars.com)

This article is published under the Creative Commons Attribution (CC BY 4.0) license. Anyone may reproduce, distribute, translate and create derivative works of this article (for both commercial and non-commercial purposes), subject to full attribution to the original publication and authors. The full terms of this license may be seen

at: http://creativecommons.org/licences/by/4.0/legalcode

Vol. 9, No. 6, 2019, Pg. $1290-1303$

http://hrmars.com/index.php/pages/detail/IJARBSS

JOURNAL HOMEPAGE

Full Terms \& Conditions of access and use can be found at http://hrmars.com/index.php/pages/detail/publication-ethics 


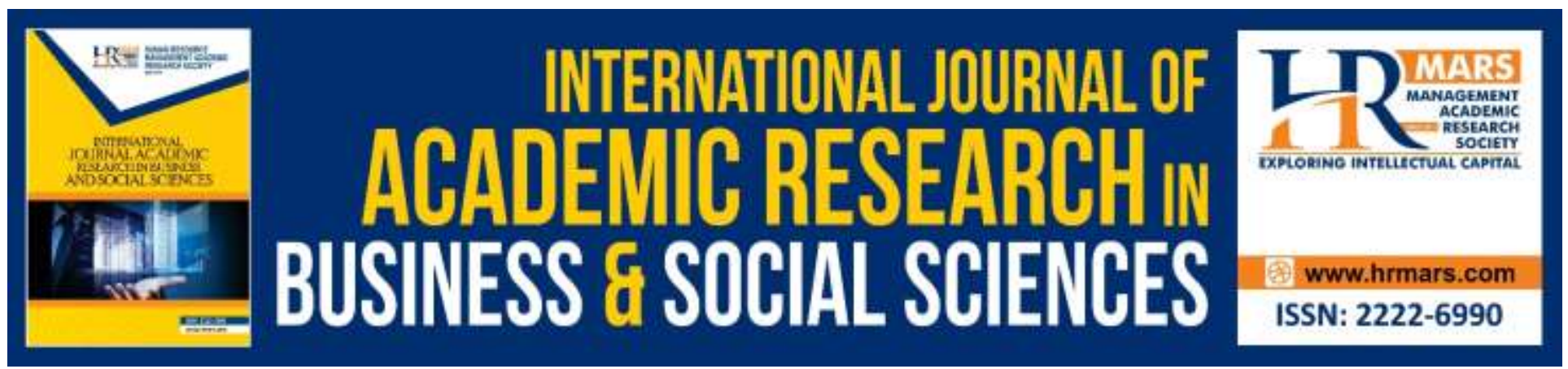

\title{
Evolution of the Tourist Offer in Romania in the Period of Accessing European Funds: Case Study, $2007-2015$
}

\author{
Anamaria - Cătălina Radu, Octavian Arsene \\ Bucharest University of Economic Studies, Faculty of Marketing, Bucharest, Romania \\ Email: anamaria_radu15@yahoo.com, octavianarsene2015@gmail.com
}

\begin{abstract}
The formation of the European Union in 1958 was seen by many specialists as an important strategic move, having the ability to influence the entire global activity. This is an economic and political union developed in Europe, currently having 28 Member States. This paper aims to analyse the tourism offer from 2007 to 2015, when many tourism projects were accessed through various programmes. Through this paper, we aim to observe whether the process of accessing European funds in tourism has left its mark on tourism offers during the reviewed period.
\end{abstract}

Keywords: Marketing, Tourism Marketing, European Funds

\section{Introduction}

The 21st century has brought about a number of changes in companies, strongly influencing the way businesses operate in the market. Paley (2000) noted that, in order to successfully implement the concept of strategic planning, organisations should lay more emphasis on the following elements:

- Focusing on consumers - Identifying and satisfying consumer needs and desires should be the focus of the marketing activity;

- Building networks - Creating links between consumers, suppliers, partners and employees through existing technologies to facilitate the transmission of information;

- Creating alliances - Organisational partnerships are the main path to their success. Creating alliances or making acquisitions is the way in which the goals of the organisation can be achieved;

- Tracking organisational culture - Understanding organisational culture, existing values and company orientation is an important component of strategic marketing. Organisational culture derives most of the time from relationships that are established between it and consumers, distributors or employees.

- Using technologies - The Internet is one of the most important parts of the strategic planning activity. It has a strong impact both on sales and on services. 
Within a company, strategic planning is very important, providing valuable information on steps to be taken at the enterprise level to meet the objectives aimed by Proctor (2008). Most of the time, strategic decisions require the existence of planned thinking over a longer period of time, somewhat in opposition to day-to-day management issues.

When making certain decisions in the organisation, it is very important to determine, on the one hand, the actions to be implemented and those to be avoided for the smooth running of the enterprise. In addition, both the potential of the organisation and the environment in which it operates must be considered. Only after these elements are established can some decisions be made to contribute to the smooth running of activities in the organisation and to the achievement of the proposed goals (McDonald, 1998).

Analysing from the perspective of the existing stages in the strategic cycle, Kotler and Keller (2008) mentioned the existence of three important processes: the planning process, the implementation process, and the control process. In this context, we can mention that strategic planning takes place both at corporate level, at division level, at the level of the strategic unit, as well as at product level. During the implementation phase, the organisation and implementation of the things established is carried out, and, in the final stage, the controlling; companies have the possibility to identify the results, to measure them and to take the most appropriate corrective measures for the existing situation.

By joining the European Union, our country has had to observe certain standards and guide its work according to certain European principles. In addition, it was given the opportunity to obtain a number of benefits made available through projects financed by European funds. According to the statistics provided by the Ministry of Finance from 2007 and until November 2015, Romania received from the European Union European funds worth about 31.94 billion Euros through the programs carried out during 2007-2013.

This value is quite high compared to the Romania's contribution of only 12.12 billion Euros. From the above, it can be noticed that Romania thus obtained a total of 19.82 billion Euros from European funds, to this amount being added the 988 million Euros, which constituted the advance provided by the European Commission for the European funds from 2014-2020.

All the amounts allocated in our country aimed the improvement of various fields of activity. Therefore, some of the projects financed by European funds targeted education, some the transport infrastructure, others the medical field, etc. Between 2007 and 2013, significant resources have also been allocated in the field of tourism through some operational programs. For example, through Priority Axis 5 of the Regional Operational Program (ROP) (fonduri-ue.ro), the beneficiaries were able to absorb European funds, both for the improvement of cultural heritage, for the creation, development and modernisation of the tourism infrastructure, and to promote tourism potential. In addition, the beneficiaries were also able to obtain European funds for tourism through the National Rural Development Program (NRDP) (pndr.ro) or through the Sectoral Operational Program Human Resources Development (SOP HRD) which gave young entrepreneurs the possibility to develop a business in this field of activity (fonduri-ue.ro). All the investments that were made in the field of tourism during this period were based on the strategies existing in the Master Plan for National Tourism (turism.gov.ro). 
INTERNATIONAL JOURNAL OF ACADEMIC RESEARCH IN BUSINESS AND SOCIAL SCIENCES Vol. 9, No. 6, June, 2019, E-ISSN: 2222-6990 @ 2019 HRMARS

Although the number of projects implemented within the country's development regions was quite high, the studies previously conducted showed that their impact was not overwhelming. Research has shown that, during the accessing process, beneficiaries have encountered various barriers that often determined to abandon the projects they managed. Moreover, late payments as well as excessive bureaucracy are other attributes that have often prevented individuals from accessing and implementing such projects.

\section{The Evolution of Tourism Accommodation Facilities}

As far as the evolution of the tourist accommodation facilities is concerned, it can be noticed that there was a total of 4,694 tourist accommodation facilities in 2007 . Of these, $27.52 \%$ were agrotourism guest houses, $22.9 \%$ were hotels, $15.68 \%$ were tourist guest houses, while $15.08 \%$ were tourist villas. As can be seen in the figure below, there was a slight increase in the tourist accommodation facilities during 2007-2010, but in 2011 there was a decrease, their number dropping to 5,003 . Subsequently, their number started to increase gradually, reaching a total of 6,821 tourist accommodation facilities in 2015 (statistici.insse.ro).

\section{Figure 1 - Evolution of the number of tourist accommodation facilities between 2007 and 2015}

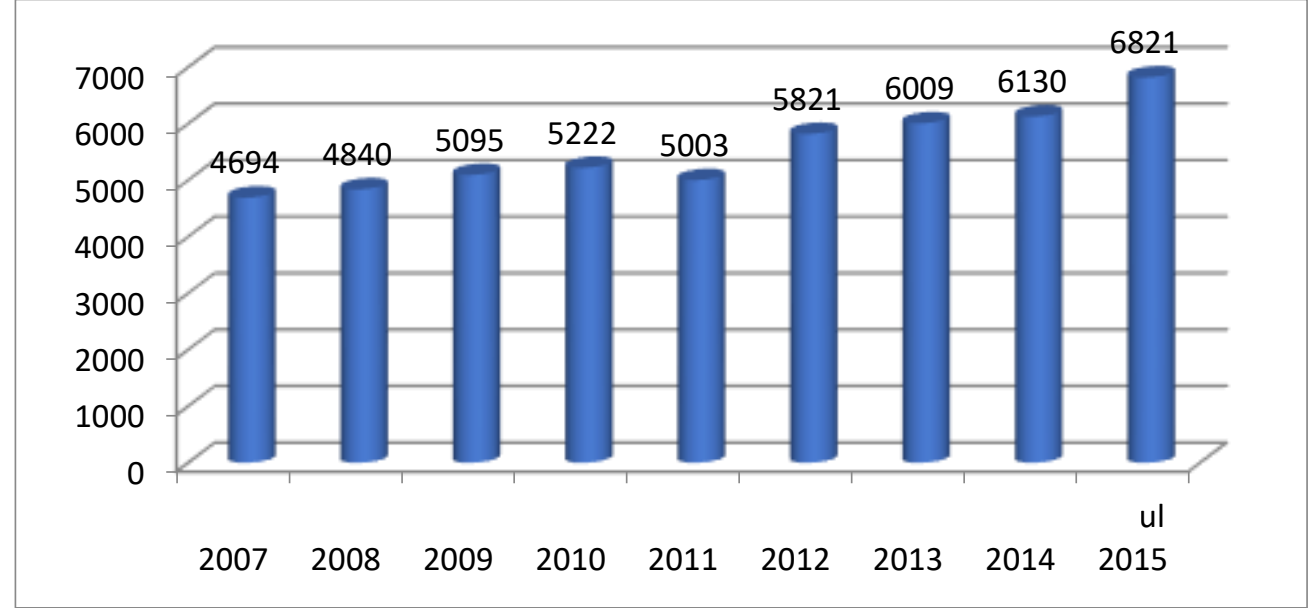

Source: statistici.insse.ro

If we look at the evolution of the country's main tourist accommodation facilities, we can see that hotels have experienced steady growth, evolving from 1,075 units in 2007 to 1,522 units in 2015. In the case of tourist villas, the evolution was sinusoidal. Thus, if in 2007 there were a total of 708 tourist villas, their number started to increase progressively by 2010, reaching 768 units. In 2011, their number decreased, dropping to 548. Subsequently, during the period 2012-2013 their number was constant - 621 units. In 2014, there was a slight increase, while in 2015 there were 643 tourist villas. In the case of tourist guest houses, it can be noticed that the evolution was constant, as in the case of hotels. Thus, they increased from 736 units in 2007 to 1,527 units in 2015. However, in 2014 there was a slight decrease in the number of tourist guest houses, dropping from 1,335 units in 2013 to 1,323 units in 2014. As far as agrotourism guest houses are concerned, it can be noticed that their number increased rapidly between 2007 and 2009, from 1,292 units to 1,412 units. The period 2010- 
INTERNATIONAL JOURNAL OF ACADEMIC RESEARCH IN BUSINESS AND SOCIAL SCIENCES Vol. 9, No. 6, June, 2019, E-ISSN: 2222-6990 @ 2019 HRMARS

2011 was not very favourable, their number dropping to 1,354 units and 1,210 units. In 2012, there was a sudden increase in the number of these accommodation facilities, with a total of 1,569 agrotourism guest houses being recorded. Starting with this year, the number of accommodation units started to increase reaching 1,918 units in 2015.

Figure 2 - Evolution of the main types of tourist accommodation facilities between 2007 and 2015

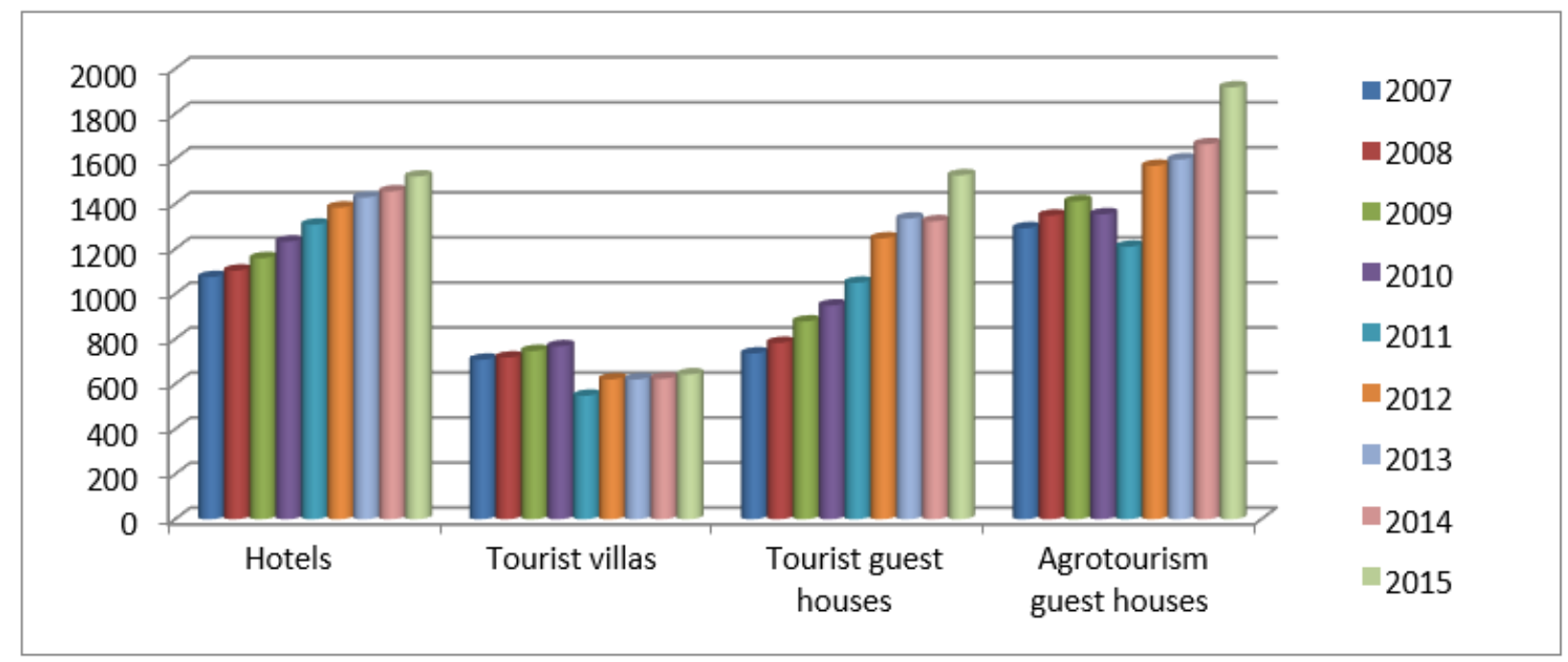

Source: statistici.insse.ro

If we analyse the evolution of the number of tourist accommodation facilities in tourist destinations, it can be noticed that, since 2007, most of the units have been recorded in mountain resorts (except for the other localities and tourist routes categories). Regarding the evolution of tourist accommodation facilities in balneary resorts, it can be stated that during 2007-2008 their number increased from 372 units to 382, dropping to 377 units in 2009. Starting with 2010, the number of tourist accommodation facilities started to increase, reaching 479 in 2015 . Starting from the evolution of tourist accommodation facilities at the seaside (except the city of Constanța), their number increased progressively during 2007 (932 units) - 2010 (1,014 units). However, in 2011 there was a sudden decrease in the number of tourist accommodation facilities, dropping to 625 accommodation units in 2011. From 2011 to 2015, the increases were slight, reaching 686 units in 2015. Mountain resorts registered the highest number of tourist accommodation facilities (except for the other localities and tourist routes categories). Thus, in 2007, there were 978 accommodation units in mountain resorts. Until 2009, they number slightly grew, cumulating a total of 1,052 accommodation units. Decreases in tourist accommodation facilities in mountain resorts were only registered in 2010, when they number dropped to 1,038 accommodation units. Starting with 2010, the number of tourist accommodation facilities has increased rapidly, registering 1,822 accommodation units in 2015.

Analysing from the perspective of tourist accommodation facilities in the Danube Delta area (including the city of Tulcea), it can be seen that this is quite low. However, during 2007-2015, it grew 
INTERNATIONAL JOURNAL OF ACADEMIC RESEARCH IN BUSINESS AND SOCIAL SCIENCES Vol. 9, No. 6, June, 2019, E-ISSN: 2222-6990 @ 2019 HRMARS

slightly from 101 to 138 accommodation units. The only year in which decreases were recorded was 2011, when the number of accommodation units decreased by 17 units.

Studying the number of tourist accommodation facilities in Bucharest and the county seats (excluding Tulcea), it can be seen that it has steadily increased between 2007 and 2013, from 836 accommodation units to 1,337 units. However, in 2014 there was a slight decrease, the number of tourist accommodation facilities dropping to 1,318 units. The year 2015 was favorable for the tourist activity in these destinations, the number of accommodation units reaching 1,450 accommodation units.

Figure 3 - Evolution of the number of tourist accommodation facilities in tourist destinations between 2007 and 2015

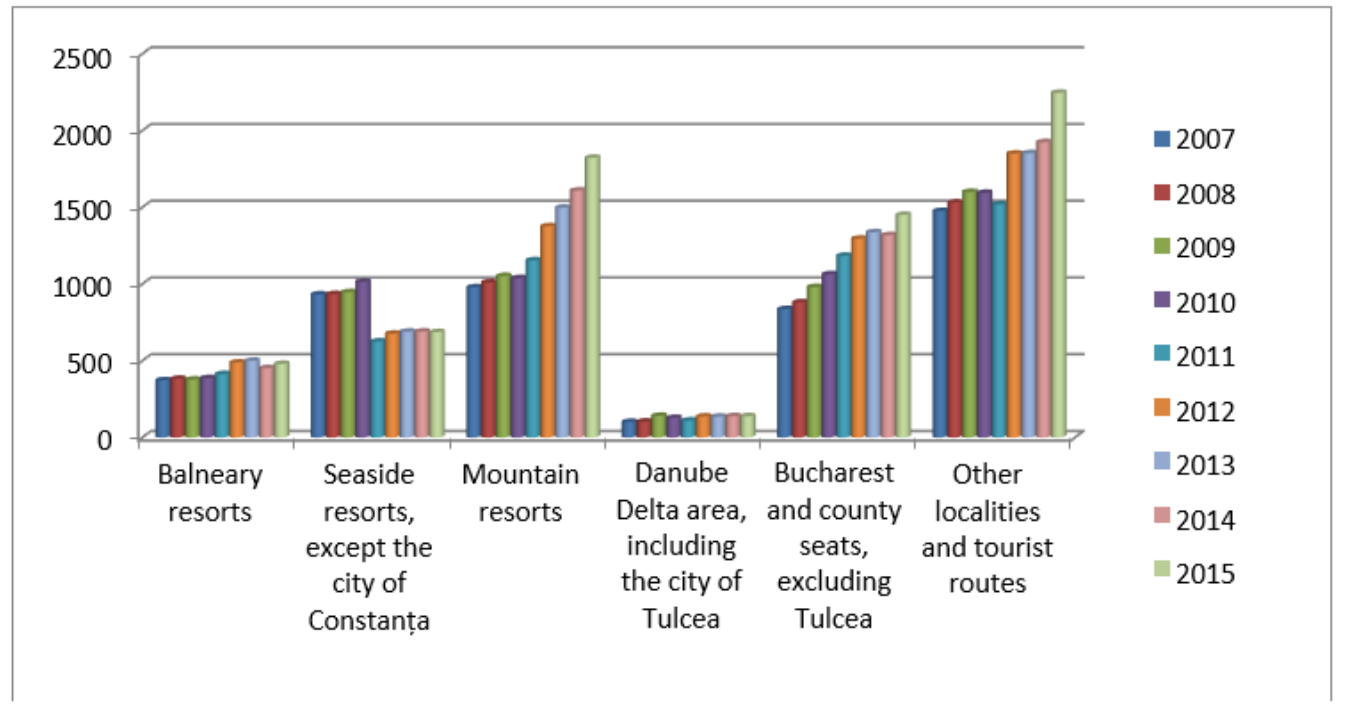

Source: statistici.insse.ro

Another important aspect studied in the case of tourist accommodation facilities was the evolution of their number in the development regions. Thus, as can be seen from the chart, at present, the highest number of tourist accommodation facilities is located in the Central region, which has accumulated a total of 2,107 units. In 2007, there were 1,209 accommodation units, their number increasing by 61 units in 2008. The period 2009-2010 was not favourable, as the number of tourist accommodation facilities in this development region suffered some decreases (1,188 in 2010). Since then, the evolution has been an upward trend, as we have previously mentioned, reaching 2,107 accommodation units.

In the North-West region, the number of tourist accommodation units is lower compared to the Central Region. Thus, during the period 2007-2010, their number increased progressively from 554 to 658 accommodation units. In 2011, there was a slight decrease, their number dropping by 8. In 2012, in the North-West region there were 730 tourist accommodation units. In the period 20132014, their number decreased to 676, but 2015 was a good year for tourism in this region, the number of accommodation establishments reaching 771. 
In the North-East Development Region, the number of tourist accommodation facilities is lower than in the other two development regions above. Between 2007 and 2015, their number increased progressively, with a significant increase taking place in 2009, when 548 accommodation units were registered (from 463 in 2008). In 2013, the number of tourist accommodation facilities grew to 725, reaching 830 tourist accommodation facilities in 2015.

The South-East region has a relatively large number of tourist accommodation units. In 2007, this region registered the highest number (127 accommodation units), and this number growing to 1,385 tourist accommodation facilities in 2010. However, 2011 was not a good year for tourism in this region, the number of accommodation units decreasing to 974 . Subsequently, it started to increase progressively, reaching 1,111 accommodation facilities in 2015.The South-Muntenia Region has a rather small number of tourist accommodation facilities. In 2007, it had a total of 426 accommodation units, registering an increase in 2011 to 533 accommodation units. Subsequently, the number of accommodation units started to increase progressively, finally reaching 740 units. The Bucharest-Ilfov Region currently has the lowest number of tourist accommodation facilities. Their number increased in 2008 by 13 reaching 164 accommodation units. In 2009, this number decreased to 154 accommodation units. In the following period, the evolution was sinusoidal, the number of accommodation establishments being 1,815 in 2015.

After the Bucharest-Ilfov region, the South-West Oltenia region has the lowest number of tourist accommodation units. In 2007 there were a total of 259 tourist accommodation facilities, but their number decreased by 4 in 2008. A visible increase was registered in 2009, when the number of accommodation facilities reached 299. Subsequently, this number started to increase slightly until 2013 when there was a decrease by 27 accommodation units. In 2015, there were 428 tourist accommodation facilities in this region. In the West region, the number of tourist accommodation facilities evolved progressively, from 389 in 2007 to 652 in 2015. A clear increase was registered in 2009, when the number of tourist accommodation facilities was 474 . The year 2014 was the only one in which the West development region registered a slight decrease compared to the previous year ($2.12 \%)$, the number of accommodation units dropping to 598. Subsequently, their number increased, reaching a total of 652 tourist accommodation units in 2015. 
INTERNATIONAL JOURNAL OF ACADEMIC RESEARCH IN BUSINESS AND SOCIAL SCIENCES

Vol. 9, No. 6, June, 2019, E-ISSN: 2222-6990 @ 2019 HRMARS

Figure 4 - Evolution of tourist accommodation facilities in the development regions between 2007 and 2015

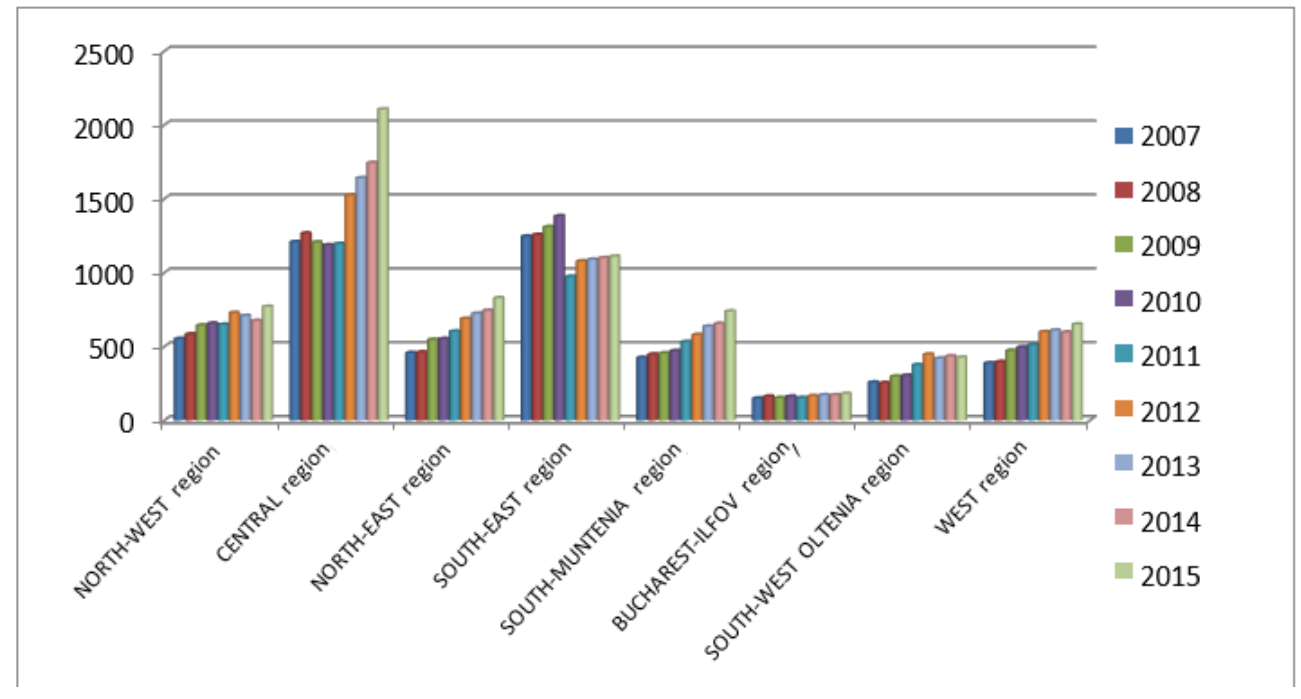

Source: statistici.insse.ro

In this subchapter, the evolution of the accommodation facilities in the period $2007-2015$ was studied in the development regions, as well as for the main types of existing resorts. As we have seen in some cases, the recorded growth was quite high, while the changes were not significant in some regions. In the next part of the paper, we studied the evolution of the tourist accommodation capacity in the period $2007-2015$.

\section{- The Evolution of the Tourist Accommodation Capacity}

Regarding the development of accommodation capacity, it should be mentioned that, in this regard, we analysed the evolution of the existing tourist accommodation capacity as well as the accommodation capacity in operation.

Regarding the evolution of the existing tourist accommodation capacity, it should be noted that the number of beds increased progressively from 283,701 in 2007 to 311,698 in 2010. Subsequently, in 2011 there was a sudden decrease $(-10.65 \%)$ in the number of existing beds, dropping to 278,503 . In 2012 , there was a relatively high growth (8.11\%) compared to the previous year, with a total of 301,109 beds. In the period 2013-2014, there was a slight increase, while in 2015 there was an increase of $5.47 \%$ compared to the previous year, the number of beds reaching 328,313 . 
INTERNATIONAL JOURNAL OF ACADEMIC RESEARCH IN BUSINESS AND SOCIAL SCIENCES Vol. 9, No. 6, June, 2019, E-ISSN: 2222-6990 @ 2019 HRMARS

Figure 5 - Evolution of tourist accommodation capacity between 2007 and 2015

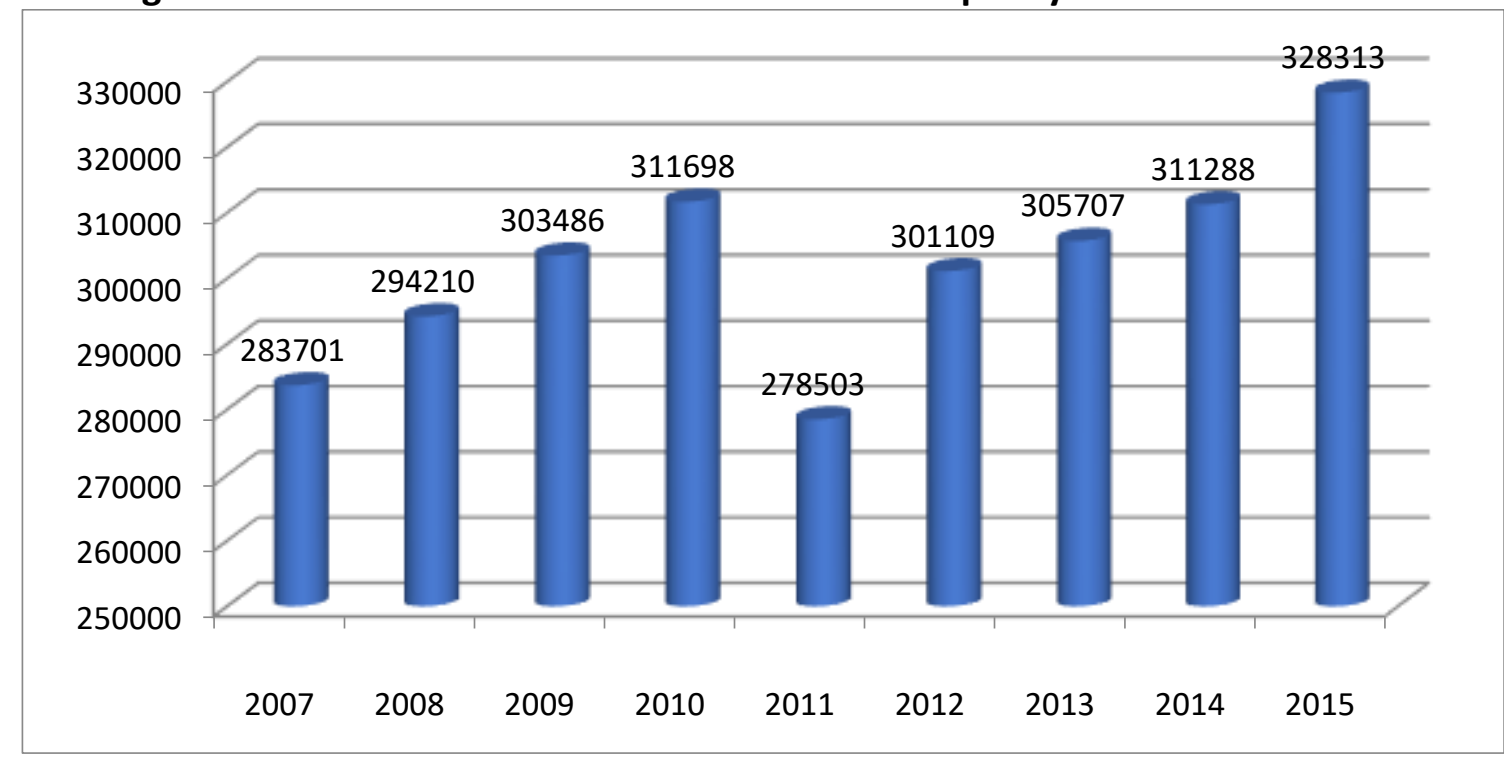

Source: statistici.insse.ro

An important aspect to be considered in terms of the current accommodation capacity in the country refers to its evolution in the main tourist destinations. Thus, as can be seen from the figure below, most of the currently existing beds are in seaside resorts, as well as in Bucharest and in county seats (excluding Tulcea).

In balneary resorts, it is noticed that the existing beds evolved sinusoidally, thus there were periods of increase and periods of decrease in the number of beds. The highest accommodation capacity was recorded in 2013 when the number of existing beds reached 39,953, while the fewest beds were registered in 2014, when their total number was 33,576.

Regarding the evolution of the existing accommodation capacity in seaside resorts, we notice that it registered the most drastic decrease. If in 2007 there were 117,864 beds, their number dropped in 2010 to 121,003 .

In 2011 , there was a decrease of $33.32 \%$ as compared to the previous period to 80.690 . Until 2015 , the changes in the accommodation capacity were not very high, the total number of beds reaching 83,353 .

Unlike seaside resorts, in mountain resorts there has been an increase in the existing accommodation capacity in recent years. If, in 2007, the number of beds was 31,448, in 2009 it increased by $12.55 \%$ compared to the previous period, reaching 35,395 .

Subsequently, progressive increases were recorded, a total of 55,775 beds being registered in 2015. In the Danube Delta (including the city of Tulcea), the number of beds was not very high. The evolution of existing beds during the period 2007-2015 was sinusoidal, with both growth periods and decrease periods over the years.

In 2007, there was a total of 3,266 beds, increasing by $45.78 \%$ compared to 2009 , reaching 4,988. Subsequently, there were no significant changes in the number of beds, with 3,907 in 2015. In Bucharest and county seats (except Tulcea), the accommodation capacity has progressively increased. If, in 2007, the number of existing beds was 53,978, in 2009 this number increased by 
INTERNATIONAL JOURNAL OF ACADEMIC RESEARCH IN BUSINESS AND SOCIAL SCIENCES Vol. 9, No. 6, June, 2019, E-ISSN: 2222-6990 @ 2019 HRMARS

$19.67 \%$ compared to the previous period, reaching 64,599 . In 2013 , the number of beds reached 80,081 , and it increased by $8.09 \%$ in 2015 , reaching 86,565 places.

\section{Figure 6 - Evolution of the existing accommodation capacity in the main types of resorts in Romania between 2007 and 2015}

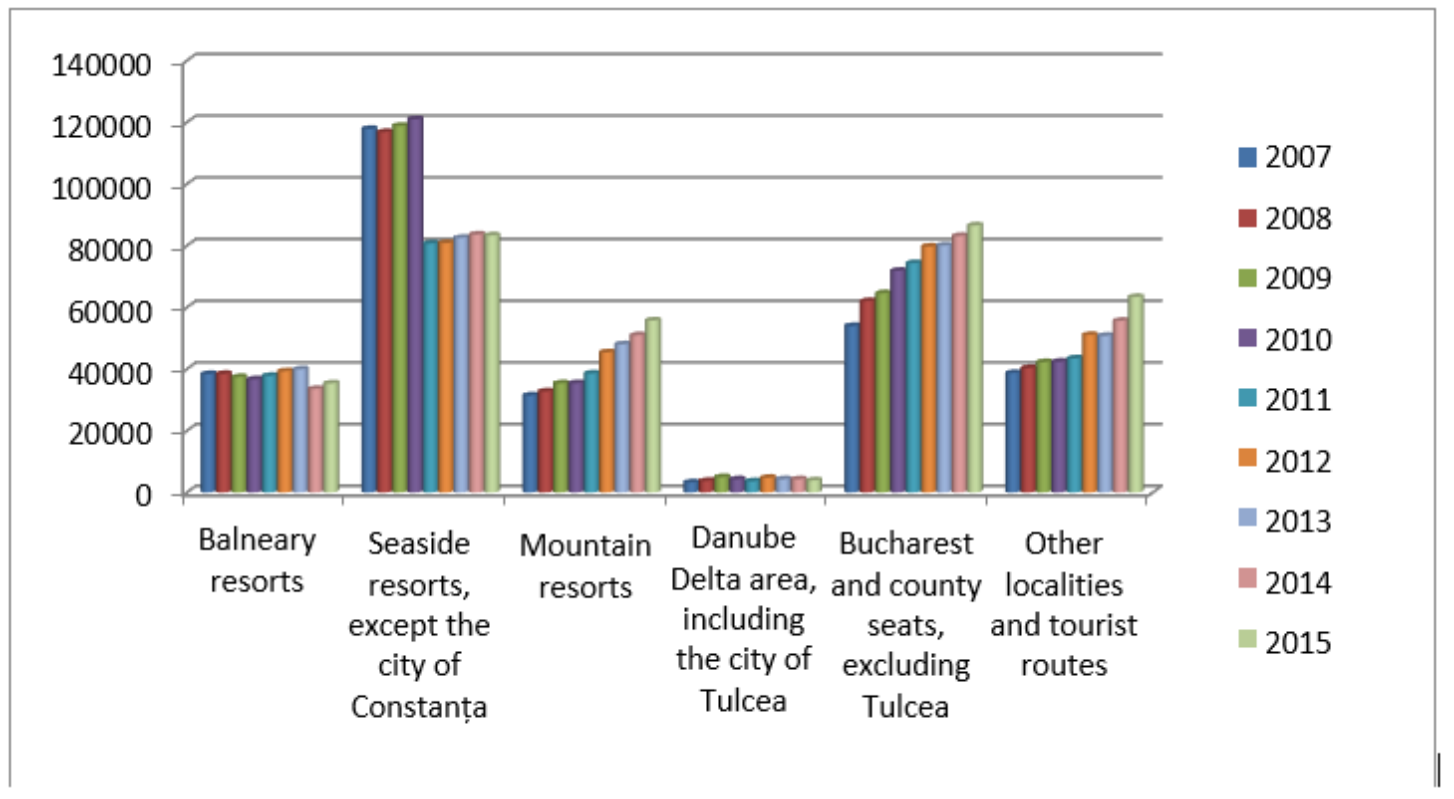

Source: statistici.insse.ro

Another important aspect that needs to be considered in terms of accommodation capacity refers to the evolution of existing beds in the development regions in the country. According to the data provided by the National Institute of Statistics, most of the existing beds are located in the SouthEast region. If we look at the evolution of tourist accommodation capacity in the North-Eest Development Region, we note that this was sinusoidal, with growth periods alternating with decreases. In 2007, the number of available beds was 26,805 . In 2008, a slight decrease was recorded, while in 2009 there was an increase of $5.29 \%$ compared to the previous year. In 2015, the number of existing beds reached 32,210 , up by $11.10 \%$ compared to the previous year.

Regarding the development of the existing accommodation capacity in the Central Development Region, it can be seen that it has registered increases in almost all years, with a decrease of $2.16 \%$ only in 2009 compared to the previous year, the number of beds dropping to 38,453 . In 2007, the total number of existing beds was 35,380. A significant increase took place in 2012, when there was an increase of $18.50 \%$ in the number existing beds, reaching 53,787. In 2015, the accommodation capacity of the Central region was 68,899 beds, which is $13.7 \%$ higher than in the previous year.

In the North-East region, the existing accommodation capacity has increased steadily since 2007 , when there was a total of 18,414 beds. A $14.70 \%$ increase was registered in 2009 , the total number of beds reaching 21,121 . In 2015 , there was a total of 28,184 beds, the highest number of beds being registered in the South-East region. Even though in 2015 there was a total of 100,921 beds 
INTERNATIONAL JOURNAL OF ACADEMIC RESEARCH IN BUSINESS AND SOCIAL SCIENCES Vol. 9, No. 6, June, 2019, E-ISSN: 2222-6990 @ 2019 HRMARS

in this region, it should be noted that this is much lower compared to the number of beds existing in $2007(132,922)$.

In the South-Muntenia Development Region, the accommodation capacity had an upward trend. Thus, in 2007 there were a total of 20,767 beds, which increased in 2011 by $16.10 \%$ compared to the previous period, reaching 24,111, and increasing further in 2015 to 29,881 .

In the Bucharest-IIfov Development Region, the existing accommodation capacity experienced a certain increase in 2007-2010. Thus, it had increased by $68.18 \%$ in 2010 compared to 2007 , registering a total of 23,120 beds. Starting with this year, the number of existing beds began to decrease dropping to 21,576 in 2015.

The accommodation capacity in the South-West Development Region has increased over the years. Thus, in 2007, there were a total of 15,219 beds, which decreased in 2008, and then increased by $9.18 \%$ compared to the previous year. A significant increase also took place in 2012 , when the number of beds increased by $9.15 \%$ compared to the previous year, reaching 19,947 . In 2015 , the total number of beds in the South-West Development Region was $18,821$.

In the West region, the existing accommodation capacity has seen a permanent increase, the only year in which a slight decrease was recorded was 2014. In 2007, the number of existing beds was 20,447 , increasing by $12.68 \%$ in 2009 compared to 2007 , and reaching a total of 23,041 beds. In 2015 , there were a total of 27,821 beds in this region.

Figure 7 - Evolution of existing accommodation capacity in the development regions of Romania between 2007 and 2015

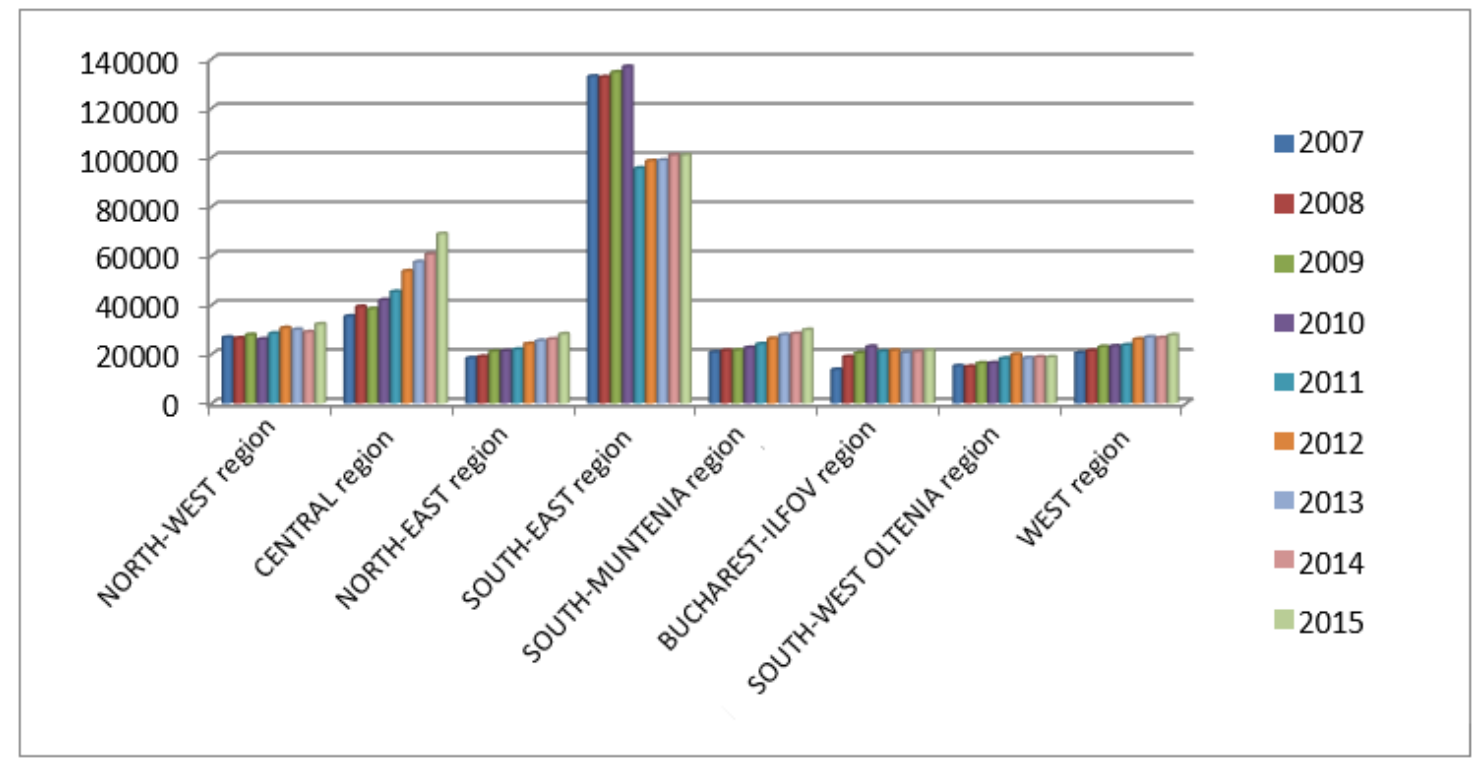

Source: statistici.insse.ro

Another important aspect to be considered refers to the tourist accommodation capacity in operation. This represents the total number of beds available to tourists in the tourist accommodation units, given the number of days these units are opened to the public during the period considered (statistici.insse.ro). 
INTERNATIONAL JOURNAL OF ACADEMIC RESEARCH IN BUSINESS AND SOCIAL SCIENCES Vol. 9, No. 6, June, 2019, E-ISSN: 2222-6990 @ 2019 HRMARS

Analysing this indicator for Romania's main tourist destinations, we noted that the highest numbers for this indicator were recorded in Bucharest and in the other county seats (except Tulcea).

Regarding the evolution of the accommodation capacity in operation in balneary resorts, we noted that this indicator registered a decrease in the period 2007-2010, going from 10,520,630 bedsdays to 9,150,435 beds-day. However, there was an increase of 5.14\% in 2011 compared to the previous year, the accommodation capacity in operation reaching 9,621,022 beds-days. A significant decrease was registered in 2014 as well, when the accommodation capacity in operation considerably decreased in balneary resorts. In that year, the registered decrease was $14.54 \%$ compared to the previous year, the indicator reaching 8,862,192 beds-day. In 2015 there was a slight increase (+ $3.09 \%)$, the accommodation capacity in operation in balneary resorts going up to $9,136,031$ bedsdays.

The evolution of this indicator in seaside resorts (except the city of Constanța) was sinusoidal, with growth periods and some decreases. In 2007, the accommodation capacity in operation in seaside resorts reached the value of 8,872,433 beds-days. In 2008, a decrease of $3.4 \%$ was recorded compared to the previous year, while in 2009 there was an increase of $6.33 \%$ compared to 2008 , reaching the value of $9,113,842$ beds-days. In 2011 , the accommodation capacity in operation increased by $14.58 \%$ compared to the previous year, this indicator reaching $10,284,146$ beds-days. There were decreases in 2012-2013, while in 2015 there was an increase of $0.89 \%$ as compared to the previous year, the indicator reaching 9,411,584 beds-days.

Analysing the accommodation capacity in operation in mountain resorts, we can mention that in 2007 the value of this indicator was 9,222,799 beds-days. In the following years, this number grew progressively, the highest increase being registered in 2012 when the accommodation capacity increased by $19.48 \%$ compared to the previous year, reaching $13,195,132$ beds-days. In 2015 , the registered increase was not significant (+ $5.33 \%$ compared to 2014), the accommodation capacity in operation being $16,004,784$ beds-days.

In the Danube Delta area, the accommodation capacity had both growth periods and decrease periods. Thus, in 2007 the value of this indicator was 548,880 beds-days, in 2008 there was a slight increase (+ 0.99\%) as compared to the previous period, and in 2009 there was a decrease by $2.09 \%$ compared to 2008 . A significant increase (+ $13.52 \%$ compared to the previous year) took place in 2012, when the accommodation capacity in the Danube Delta area reached 643,545 beds-days. However, in 2014 it fell sharply (-13.26\% compared to 2013), the accommodation capacity in operation being a total of 570,201 places-days. The year 2015 was not favourable for this destination, the accommodation capacity in operation decreasing by $1.74 \%$ compared to $2014(560,259$ places days).

In Bucharest and other county seats (excluding Tulcea), the evolution of accommodation capacity in operation had an upward trend from 2007 until 2015. Thus, in the first year of analysis, the value of this indicator was $18,620,946$ beds-days, with an increase of $10.10 \%$ in 2008 compared to the previous year. An equally important increase of this indicator was recorded in 2012, when the accommodation capacity in operation increased by $9.21 \%$ compared to the previous year, reaching $27,269,836$ beds-days. In 2015 , the evolution was an ascending one, the accommodation capacity in operation increasing by $5.64 \%$ compared to the previous year, reaching a total of $29,586,854$ bedsdays. 
INTERNATIONAL JOURNAL OF ACADEMIC RESEARCH IN BUSINESS AND SOCIAL SCIENCES

Vol. 9, No. 6, June, 2019, E-ISSN: 2222-6990 @ 2019 HRMARS

Figure 8 - Evolution of the accommodation capacity in operation in the main types of resorts in the country between 2007 and 2015

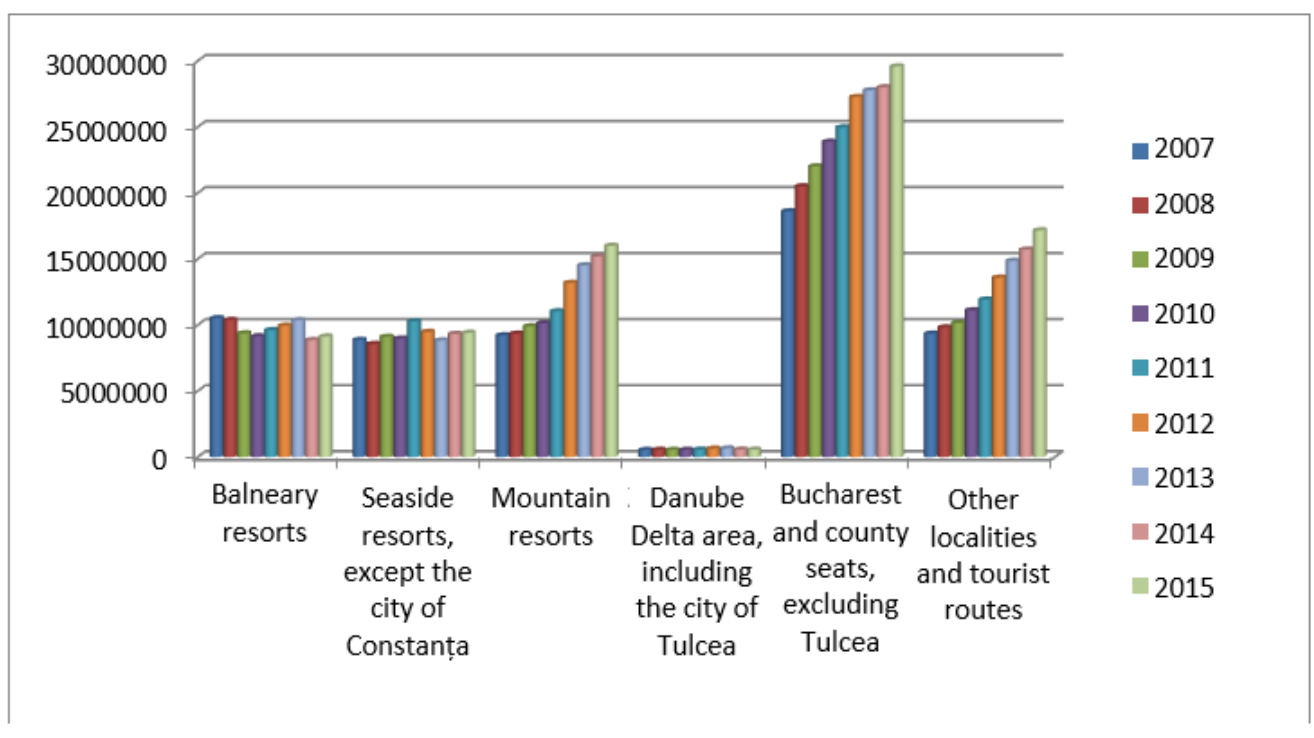

Source: statistici.insse.ro

If we are to analyse the evolution of this indicator in the development regions of Romania, we can see that the highest values were recorded in the Central Development Region, in the South-East Development Region, as well as in the North-West Development Region. The most unexpected growth occurred in the Central Development Region (it increased by $88.14 \%$ in 2015 compared to 2007), reaching $19,711,780$ beds-days. A significant increase compared to 2007 occurred in the Bucharest-Ilfov Development Region as well, where in 2015 the tourist accommodation capacity increased by $65.65 \%$ compared to 2007 , reaching $7,901,387$ beds-days.

In the North-East and South-West regions, the accommodation capacity in operation in 2015 was $8,088,607$ beds-days (44.86\% higher compared to 2007), and 5,896,684 beds-days (43.56\% higher compared to 2007), respectively. Lower growths were seen in the South-Muntenia Development Region (+ 33.38\% compared to 2007, with 8,523,073 beds-days), in the West Development Region (+ 32.07\%, with 7,453,990 beds-days), in the North-West Development Region (+ 31.64\% compared to 2007, with 9,855,757 beds-days), as well as in the South-East Development Region (+ 13.89\%, with 14,441,261 beds-days). 
INTERNATIONAL JOURNAL OF ACADEMIC RESEARCH IN BUSINESS AND SOCIAL SCIENCES Vol. 9, No. 6, June, 2019, E-ISSN: 2222-6990 @ 2019 HRMARS

Figure 9 - Evolution of accommodation capacity in operation in the development regions of Romania between 2007 and 2015

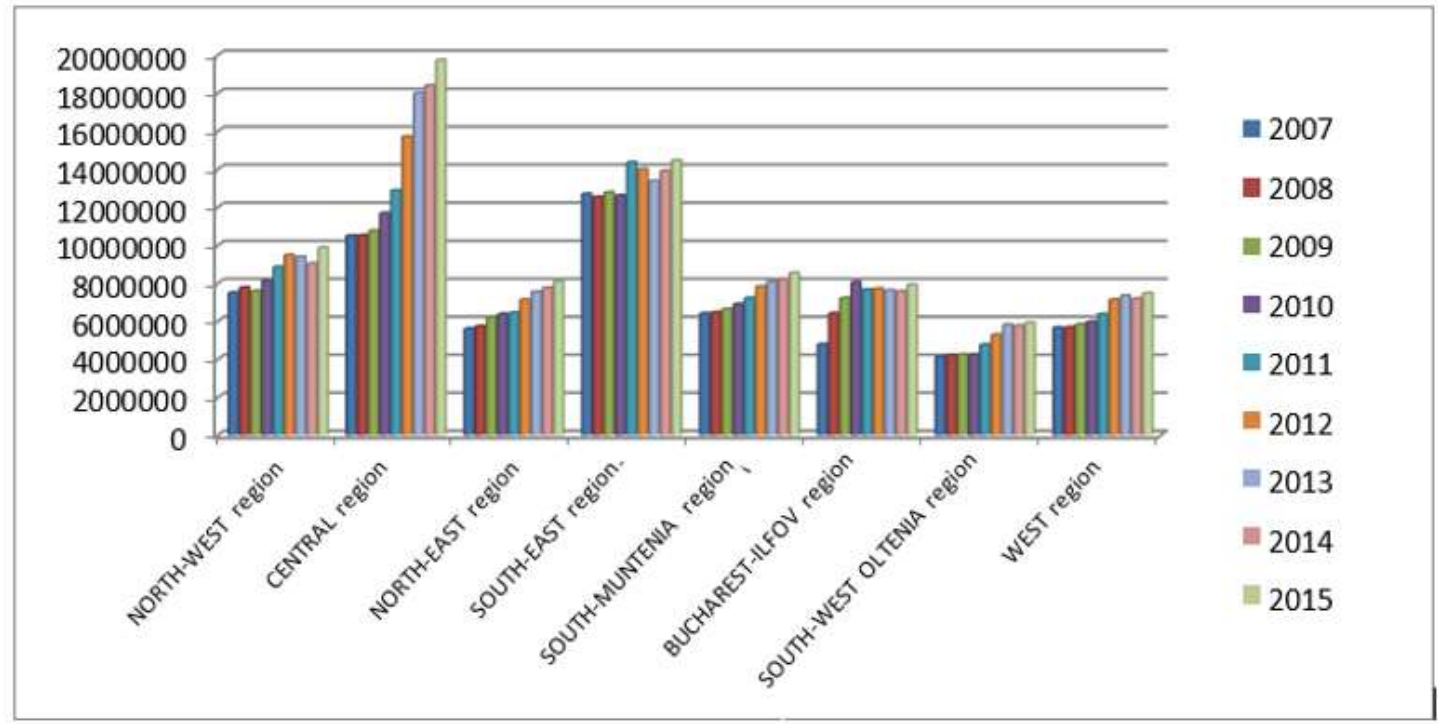

Source: statistici.insse.ro

\section{Conclusions}

The creation and development of the European Union has brought a number of benefits to all Member States. The functioning of the European Union is managed by a number of supranational institutions that constantly communicate with the Member States on the issues they face. In addition, activities in the Union are governed by a series of legislative rules and regulations to be observed by each member country. Romania's accession to the European Union took place on 1 January 2007. This date was proposed and accepted at the Thessaloniki Summit in 2003, confirmed later in 2004 in Brussels.

In this paper, we studied the way the tourist offer evolved between 2007 and 2015. For this, we studied two important indicators, namely the evolution of the tourist accommodation facilities and the evolution of the tourist capacity. As a result of the analysis, it has been noticed that, for certain destinations, the number of accommodation units has increased considerably, largely due to the investments that have been made in these areas. In some cases, these investments were made through projects financed by European funds. Concluding, we can mention that projects financed by European funds have a very important role in tourism, supporting the increase and improvement of the tourist infrastructure at destination level.

\section{References}

1. Paley, N. (2000) Marketing strategy desktop guide, London: Hawksmere

2. Proctor, T. (2008) Strategic marketing: an introduction, Ediția a II-a, London : Routledge

3. McDonald, M. (1998) Marketing strategic, Bucuresti : Codecs

4. Kotler, Ph., Keller, K. L. (2008) Managementul marketingului, Ediția a V-a, Bucuresti : Teora 